\title{
NOTE
}

\section{Acute hepatopancreatic necrosis disease (AHPND) outbreaks in Penaeus vannamei and $P$. monodon cultured in the Philippines}

\author{
Leobert D. de la Peña ${ }^{1, *}$, Nikko Alvin R. Cabillon ${ }^{1}$, Demy D. Catedral ${ }^{1}$, \\ Edgar C. Amar ${ }^{1}$, Roselyn C. Usero ${ }^{2}$, Wilberto D. Monotilla ${ }^{3}$, Adelaida T. Calpe ${ }^{4}$, \\ Dalisay DG. Fernandez ${ }^{4}$, Cynthia P. Saloma ${ }^{3}$ \\ ${ }^{1}$ Aquaculture Department, Southeast Asian Fisheries Development Center (SEAFDEC/AQD), Tigbauan, Iloilo 5021, \\ Philippines \\ ${ }^{2}$ Negros Prawn Producers Cooperative (NPPC), Bacolod City, Negros Occidental 6100, Philippines \\ ${ }^{3}$ Philippine Genome Center (PGC), University of the Philippines Diliman, Quezon City 1101, Philippines \\ ${ }^{4}$ Philippine Council for Agriculture, Aquatic and Natural Resources Research and Development (PCAARRD), \\ Paseo de Valmayor, Timugan Los Baños, Laguna 4030, Philippines
}

\begin{abstract}
Acute hepatopancreatic necrosis disease (AHPND) has recently emerged as a serious disease of cultured shrimp. It has also been described as early mortality syndrome (EMS) due to mass mortalities occurring within 20 to $30 \mathrm{~d}$ after stocking of ponds with postlarvae. Here, Penaeus vannamei and Penaeus monodon from shrimp farms in the Philippines were examined for the toxin-producing strain of Vibrio parahaemolyticus due to AHPND-like symptoms occurring in marketable size shrimp. In the P. vannamei, histology revealed typical AHPND pathology, such as sloughing of undifferentiated cells in the hepatopancreatic tubule epithelium. Analysis using the IQ2000 AHPND/EMS Toxin 1 PCR test generated $218 \mathrm{bp}$ and $432 \mathrm{bp}$ amplicons confirmative of the toxin-producing strain of $V$. parahaemolyticus among shrimp sampled from 8 of 9 ponds. In the $P$. monodon, histology revealed massive sloughing of undifferentiated cells of the hepatopancreatic tubule epithelium in the absence of basophilic bacterial cells. PCR testing generated the 2 amplicons confirmatory for AHPND among shrimp sampled from 5 of 7 ponds. This study confirms the presence of AHPND in P. vannamei and P. monodon farmed in the Philippines and suggests that the disease can also impact late-stage juvenile shrimp.
\end{abstract}

KEY WORDS: AHPND $\cdot$ P. vannamei $\cdot$ P. monodon $\cdot$ PCR $\cdot$ Histopathology $\cdot$ Philippines

A disease described initially as early mortality syndrome (EMS), and subsequently as acute hepatopancreatic necrosis disease (AHPND) based on its characteristic histopathology, has recently been the cause of mass mortalities and significant production losses of shrimp farmed in China since 2009, Vietnam since 2010, Malaysia since 2011 and Thailand since 2012 (Bondad-Reantaso et al. 2012, Lightner et al. 2012, Joshi et al. 2014). Shrimp affected by AHPND characteristically display a pale to white discoloured hepatopancreas as well as atrophy of $>50 \%$ of the organ mass. Due to melanin deposits forming as a result of hemocyte activity, black spots in the hepatopancreas become visible in the terminal phase of disease (Tran et al. 2013). Disease signs associated with mortality typically appear within 20 to $30 \mathrm{~d}$ after stocking ponds with postlarvae (Lightner et al. 2012).

The causative agent for AHPND has been identified as a toxin-producing strain of Vibrio parahaemolyticus (Tran et al. 2013). V. parahaemolyticus strains 
are found commonly in diseased $P$. monodon (Ruangpan \& Kitao 1991) and, together with other Vibrio species, have been associated with red disease syndrome (Alapide-Tendencia \& Dureza 1997). Together with $V$. alginolyticus and Pseudomonas sp., V. parahaemolyticus strains have also been associated with bacterial septicaemia (Anderson et al. 1988). Moreover, a strain of $V$. parahaemolyticus has been associated with red-leg disease characterized by an expansion of red chromatophores in the swimmerets and walking legs of P. monodon (Chen 1992). V. parahaemolyticus has also been isolated in low numbers from haemolymph sampled from healthy $P$. vannamei (Gomez-Gil et al. 1998).

EMS/AHPND was first reported in China in 2009. However, it was ignored initially until disease outbreaks became more serious early in 2011, resulting in $\sim 80 \%$ production losses in the provinces of Hainan, Guangdong, Fujian and Guangxi (Leaño \& Mohan 2012). Later in 2011, AHPND outbreaks occurred in $P$. vannamei farmed in Malaysia that resulted in significant production losses valued at 100 million USD (FAO 2013), and unprecedented losses of farmed P. monodon valued at 1.5 trillion Vietnamese Dong occurred in the province of Soc Trang in the Mekong Delta in Vietnam (Lyon et al. 2013). The onset of AHPND in Thailand in 2012 to 2013 decreased shrimp production $\sim 54 \%$ through a combination of disease and a reluctance of farmers to stock ponds due to the fear of disease. Up to 2013, direct and indirect losses to the Asian shrimp culture sector due to AHPND have been estimated to be in the order of 1 billion USD (FAO 2013). Moreover, since 2013, several countries have suspended or banned imports of live shrimp and shrimp products from countries affected by AHPND. In the Philippines, the Bureau of Fisheries and Aquatic Resources (BFAR) has also banned imports of other crustaceans that might act as carriers of AHPND.

Between 2013 and 2014, production volumes of $P$. vannamei and $P$. monodon in the Philippines decreased due to disease outbreaks primarily in Luzon and the Visayas areas (Bureau of Agricultural Statistics 2014) suspected to have been caused by AHPND. The present study was undertaken to identify whether AHPND contributed to this lost production.

P. monodon were sampled from a farm in late 2014 when production of $P$. vannamei and $P$. monodon notably decreased, and $P$. vannamei were sampled in early 2015 from farms in Bohol experiencing disease problems (Bureau of Agricultural Statistics 2014). At the P. monodon farm, mortality rates of up to $40 \%$ occurred after 56 to $94 \mathrm{~d}$ of culture (DOC) among ponds stocked at a density of 23 shrimp $\mathrm{m}^{-2}$. At the $P$. vannamei farm, mortality rates of up to $60 \%$ occurred after 56 to 94 DOC among ponds stocked at 50 shrimp $\mathrm{m}^{-2}$. The numbers of dead shrimp recovered at the pond bottom increased daily, and clinical signs of AHPND, including weakness as well as pale to white discoloration and atrophy of the hepatopancreas, coincided with the mortalities. After sampling, the affected ponds were emergency harvested.

Groups of 10 moribund $P$. vannamei were sampled from each of 9 ponds, and groups of 5 moribund $P$. monodon were sampled from each of 7 ponds (Table 1). Tissue samples for PCR were either frozen at $-80^{\circ} \mathrm{C}$ or fixed in $95 \%$ ethanol and stored at $4^{\circ} \mathrm{C}$, and samples for histology were fixed in Davidson's fixative and transported to the Southeast Asian Fisheries Development Center Aquaculture Department (SEAFDEC/AQD), Tigbauan, Iloilo, Philippines, for processing.

Among the moribund $P$. vannamei and $P$. monodon examined (Figs. 1 \& 2), histology on 5 to $7 \mu \mathrm{m}$ thick sections of hepatopancreas tissue stained with haematoxylin and eosin (H\&E) revealed manifestations of typical AHPND pathology (Tran et al. 2013). These manifestations included severe tissue necrosis associated with sloughing of undifferentiated cells of hepatopancreatic tubules and the absence of basophilic bacterial cells. Among the P. vannamei, histopathology was evident in 4 of 6 shrimp examined from Pond 16 and 5 of 6 shrimp examined from Pond 27.

Table 1. Pond details of the $P$. vannamei and $P$. monodon from a farm in Bohol, Philippines, sampled in early 2015 and late 2014, respectively. DOC: days of culture; ABW: average body weight

\begin{tabular}{|lcc|}
\hline Pond & DOC & ABW $(\mathrm{g})$ \\
\hline Penaeus vannamei & & \\
1 & 71 & 10 \\
7 & 71 & 9 \\
12 & 94 & 12 \\
13 & 94 & 13 \\
16 & 58 & 7 \\
19 & 56 & 7 \\
20 & 60 & 6 \\
21 & 63 & 7 \\
27 & 67 & 8 \\
Penaeus monodon & & \\
33 & 66 & 15 \\
35 & 60 & 14 \\
36 & 60 & 14 \\
37 & 40 & 6 \\
38 & 46 & 6 \\
40 & 52 & 8 \\
41 & 40 & 7 \\
\hline
\end{tabular}



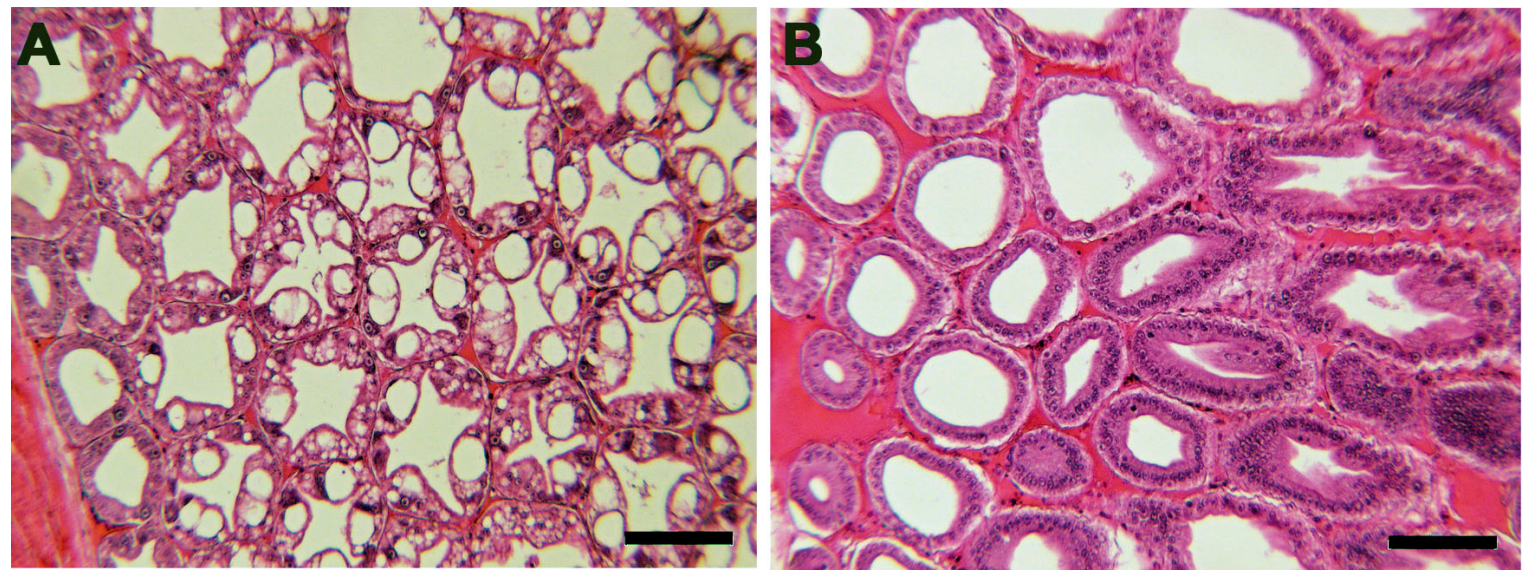

Fig. 1. H\&E stained histological sections of the hepatopancreas of $P$. vannamei (Pond 27,67 DOC) sampled from a farm in Bohol. (A) Normal shrimp hepatopancreatic histology; (B) AHPND pathology characterized by sloughing of undifferentiated epithelial cells of the hepatopancreatic tubule epithelia. Scale bars $=100 \mu \mathrm{m}$
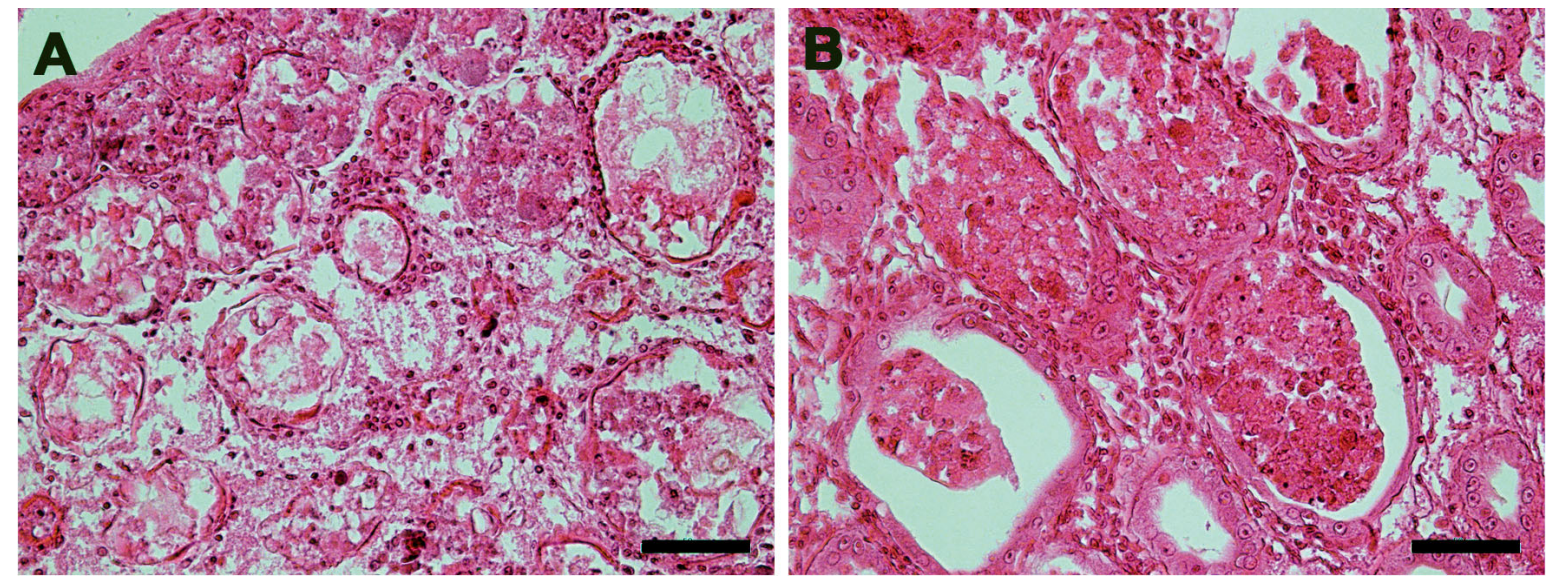

Fig. 2. H\&E stained histological sections of the hepatopancreas of moribund P. monodon sampled from a farm in Bohol. (A) Massive necrotic sloughing of tubule epithelial cells in the hepatopancreas (Pond 38, 46 DOC); (B) typical AHPND at the acute stage of disease showing sloughing of tubule epithelial cells in the absence of basophilic bacterial cells (Pond 33, 66 DOC). Scale bars $=50 \mu \mathrm{m}$

Among the P. monodon, histopathology was evident in all 5 shrimp examined from Ponds 33 and 38.

Using DNA extraction and PCR methods recommended for the IQ2000 AHPND/EMS Toxin 1 Detection and Prevention System (GeneReach Biotechnology, Taiwan), the presence of $V$. parahaemolyticus (432 bp amplicon) together with the toxin-producing plasmid (218 bp amplicon) associated with AHPND was evident among $P$. vannamei sampled from 8 of 9 ponds and $P$. monodon sampled from 5 of 7 ponds (Fig. 3).

Based on the observed histopathology and PCR data, the presence of AHPND was confirmed for the first time to be affecting $P$. vannamei and $P$. monodon being cultured in the Philippines. However, unlike classical AHPND in which disease commonly arises within 20 to $30 \mathrm{~d}$ of ponds being stocked with postlarvae (Lightner et al. 2012), disease symptoms and mortality were identified here to be present significantly later in the culture cycle, between 46 and $96 \mathrm{~d}$ after pond stocking. While other factors might have been involved in the mortalities, our data suggest that older shrimp life stages remain susceptible to the disease.

Acknowledgements. We are very grateful to DOST-PCAARRD and SEAFDEC/AQD for funding this work and to the Shrimp Pathogenomics team, especially Dr. N. R. L. Rojas and Dr. E. P. Enriquez. We thank the shrimp farms that provided the samples and the staff of Fish Health Section Diagnostic Services and Microtechnique Lab for the technical support. We also thank T. W. Flegel for confirming our histological analysis and for assistance in editing the manuscript. 


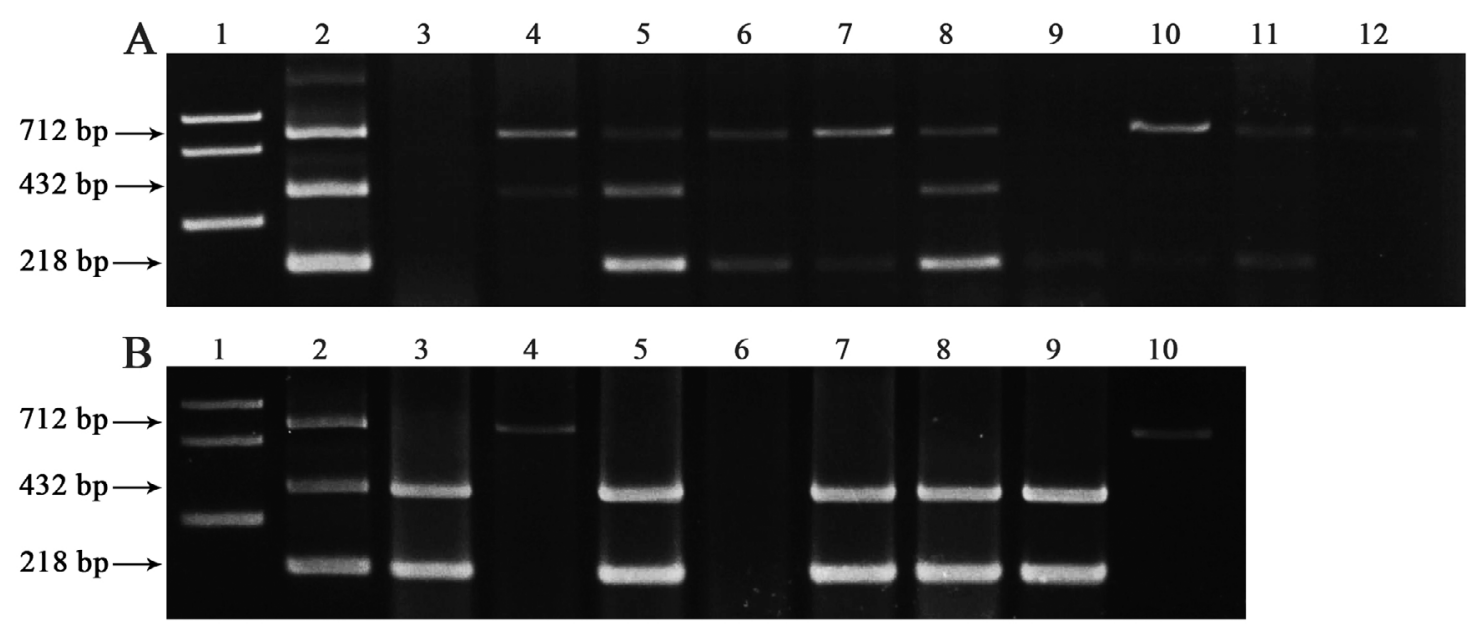

Fig. 3. Agarose gel electrophoresis of DNA products amplified using the IQ2000 AHPND PCR test. (A) P. vannamei samples, DNA marker (Lane 1), AHPND positive control (Lane 2), Ponds 1, 7, 12, 13, 16, 19, 20, 21 and 27 (Lanes 3 to 11, respectively) and negative control (Lane 12). (B) P. monodon samples, DNA marker (Lane 1), AHPND positive control (Lane 2), Ponds 33, 35, 36, 37, 38, 40 and 41 (Lanes 3 to 9, respectively) and negative control (Lane 10). The AHPND DNA positive control consisted of a plasmid containing the AHPND toxin 1 gene and an AHPND plasmid pAP1 marker that yielded PCR amplicons of $218 \mathrm{bp}$ and $432 \mathrm{bp}$, respectively. Non-virulent isolates of $V$. parahaemolyticus that carry the AHPND plasmid pAP1 containing no toxin gene generate the $432 \mathrm{bp}$ amplicon only. Negative samples generate an internal $712 \mathrm{bp}$ control amplicon only to confirm the integrity of the shrimp DNA extract

\section{LITERATURE CITED}

Alapide-Tendencia EV, Dureza L (1997) Isolation of Vibrio spp. from Penaeus monodon (Fabricius) with red disease syndrome. Aquaculture 154:107-114

Anderson IG, Shamsudin MN, Shariff M, Nash G (1988) Bacterial septicemia juvenile tiger shrimp, Penaeus monodon, cultured in Malaysian brackishwater ponds. Asian Fish Sci 2:93-108

Bondad-Reantaso MG, Subasinghe RP, Josupeit H, Cai J, Zhou X (2012) The role of crustacean fisheries and aquaculture in global food security: past, present and future. J Invertebr Pathol 110:158-165

Bureau of Agricultural Statistics (BAS) (2014) Aquaculture: volume of production by species, by region and by province, 1996-2014. http://countrystat.psa.gov.ph/?cont =10\&pageid=1\&ma=D80PNCAP (Accessed 17 March 2015)

Chen D (1992) An overview of the disease situation, diagnostic techniques, treatments and preventives used on shrimp farms in China. In: Fulks W, Main KL (eds) Diseases of cultured penaeid shrimp in Asia and the United States. The Oceanic Institute, Honolulu, HI, p 47-55

FAO (2013) FAO/MARD Technical workshop on early mortality syndrome (EMS) or acute hepatopancreatic necrosis syndrome (AHPNS) of cultured shrimp (under TCP/VIE/3304). FAO Fisheries and Aquaculture Report No. 1053, FAO, Rome

Editorial responsibility: Jeff Cowley,

Brisbane, Queensland, Australia
Gomez-Gil B, Tron-Mayén L, Roque A, Turnbull JF, Inglis V, Guerra-Flores AL (1998) Species of Vibrio isolated from hepatopancreas, haemolymph and digestive tract of a population of healthy juvenile Penaeus vannamei. Aquaculture 163:1-9

Joshi J, Srisala J, Truong VH, Chen IT and others (2014) Variation in Vibrio parahaemolyticus isolates from a single Thai shrimp farm experiencing an outbreak of acute hepatopancreatic necrosis disease (AHPND). Aquaculture 428-429:297-302

Leaño EM, Mohan CV (2012) Early mortality syndrome (EMS)/ acute hepatopancreatic necrosis syndrome (AHPNS): an emerging threat to the Asian shrimp industry. NACA, Bangkok

Lightner DV, Redman RM, Pantoja CR, Noble BI, Tran L (2012) Early mortality syndrome affects shrimp in Asia. Glob Aquacult Advocate Jan/Feb 2012:40

Lyon A, Mooney A, Grossel G (2013) Using AquaticHealth.net to detect emerging trends in aquatic animal health. Agriculture 3:299-309

Ruangpan L, Kitao T (1991) Vibrio bacteria isolated from black tiger shrimp, Penaeus monodon Fabricus. J Fish Dis 14:383-388

Tran L, Nunan L, Redman R, Mohney L, Pantoja C, Fitzsimmons K, Lightner D (2013) Determination of the infectious nature of the agent of acute hepatopancreatic necrosis syndrome affecting penaeid shrimp. Dis Aquat Org 105:45-55

Submitted: June 4, 2015; Accepted: August 25, 2015 Proofs received from author(s): October 9, 2015 